\title{
RANCANG BANGUN \\ SISTEM INFORMASI EMOSI SISWA MENGGUNAKAN EMOTICON BERBASIS WEB STUDY KASUS PADA SDIT BUNAYYA PERMATA TANGERANG
}

\author{
Muhammad Aji Khoirun (1) \\ Sri Mulyati (2)
}

\author{
Program Studi Informatika \\ Fakultas Teknik Universitas Muhammadiyah Tangerang \\ Jl. Perintis Kemerdekaan 1/33 Cikokol Kota Tangerang \\ Lilysrimulyati@gmail.com, Muhammad.Aji@gmail.com
}

\begin{abstract}
SDIT BUNAYYA is a private elementary school located in the Pasarkemis region of Tangerang Regency. Character-based SDIT Bunayya that pays attention to students' emotions to find out the development of students. In SDIT Bunayya in emotional data students still use the manual in writing to take time when reporting and when they want to observe student emotions. Thus the author tries to design an emotional data processing system for students using websitebased emoticons that can help the process of data collection of teacher and student attendance and recording emotions for students during learning in school. In developing this system the author uses the PHP programming language with the concept of MVC (Model, View, Controller) to make it easier in its development with the Codelgniter framework, System Analysis Methods using Object Oriented Analysis and Design (OOAD) and use UML (Unified Modeling Language) as a tool and the design method uses the waterfall model.

The construction of this data processing system begins with the process of analyzing system requirements and is followed by a system design planning process based on the results of the needs analysis. The last stage of this drafting process is the implementation of the system into a new system. In this final assignment, it can be concluded that the system built to help the emotional data collection process can display the results of handling emotional information of students for the Principals of SDIT Bunayya, Homeroom Class and Teacher Budi Pekerti at SDIT Bunayya.

Keywords: Information Systems, emoticons, PHP, Codelgniter Framework.
\end{abstract}

\section{PENDAHULUAN}

\subsection{Latar Belakang Masalah}

Perkembangan teknologi informasi sekarang semakin berkembang pesat di segala bidang sehingga banyak perusahaan dan instansi-instansi terus berusaha meningkatkan pengolahan data yang lebih efektif dan efisien guna menunjang produktifitas kerja. Manfaat dari perkembangan teknologi informasi yang sangat penting adalah penggunaan alat pengolah data yang berfungsi menghasilkan informasi yang dibutuhkan secara cepat, akurat, relevan, serta tepat sasaran. Perusahaan ataupun instansi yang akan maju dan sukses harus mengikuti era informasi dengan menggunakan pendukung pengolah data yaitu komputer.

Dalam sistem pendidikan penting sekali dalam mendata kehadiran, kehadiran tersebut digunakan sebagai acuan dalam menilai kedisiplinan setiap orang yang ada di dalam proses pendidikan. Mulai dari Kepala Sekolah,
Guru , Staff, Office Boy hingga siswa. Keakuratan kehadiran setiap orang sangat penting untuk dilakukan.

Sekolah Islam yang berbasis Karakter sangat memerlukan data emosi siswa setiap hari untuk menentukan langkah-langkah yang harus dilakukan sekolah dalam proses pendidikan kepada siswa agar karakter-karakter tersebut dapat tertanam baik dalam diri siswa. Karakter ini menjadi tuntutan bagi Sekolah Islam yang berbasis karakter sehingga perlu adanya perhatian lebih dalam mengawasi dan memperlakukan peserta didik demi tercapainya karakter-karakter kepribadian yang positif. Memang dalam Kurikulum baru yang bernama kurikulum 2013, seluruh sekolah harus menerapkan sifatsifat karakter namun sekolah Islam telah melaksanakannya jauh sebelum kurikulum 2013 itu diperkenalkan.

Guru Budi Pekerti memerlukan laporan emosi siswa dalam menyelesaikan permasalahan siswa yang terjadi di sekolah, namun karena tidak adanya 
pencatatan oleh guru menjadi menyelesaikan permasalahan siswa yang terjadi di sekolah dalam hal proses pembelajaran.

Penulis akan membuat inovasi dengan membuat sistem pencatatan emosi, menganalisis dan melaporkan tindakan yang harus dilakukan oleh pegawai SDIT Bunayya. Penulis akan melakukan penelitian untuk melakukan Tugas Akhir dengan judul "Rancang Bangun Sistem Informasi Emosi Siswa menggunakan Emoticon Berbasis Web Studi Kasus pada SDIT Bunayya Permata Tangerang".

\subsection{Tujuan dan Manfaat Penelitian}

\subsubsection{Tujuan Penelitian}

Penelitian ini bertujuan untuk merancang (membuat) serta mengimplementasikan suatu sistem informasi kehadiran bagi guru dan siswa berbasis web menggunakan emoticon di SDIT Bunayya guna untuk mempermudah dan memperlancar mengelola data kehadiran dan data emosi guru dan siswa untuk berbagai laporan dan acuan tindakan terhadat peserta didik.

Tujuan dari penelitian ini adalah :

1. Menganalisis sistem informasi emosi siswa yang berjalan pada SDIT Bunayya.

2. Merancang sistem informasi emosi siswa menggunakan emoticon di SDIT Bunayya.

3. Merancang sistem laporan emosi SDIT Bunayya dengan berbasis web.

\subsubsection{Manfaat Penelitian}

1. Manfaat penelitian perancangan sistem informasi berbasis web ini adalah bagi guru kelas dan guru budi pekerti tentang data emosi siswa dalam proses pembelajaran.

2. Manfaat penelitian perancangan sistem informasi berbasis web bagi Guru Budi Pekerti dapat memantau Emosi para siswa dan siswi sebagai bahan acuan dalam mendidik peserta didik.

3. Manfaat penelitian perancangan sistem informasi berbasis web bagi Orang Tua/Wali Murid dapat mengetahui dan memantau emosi yang terjadi pada anaknya masingmasing untuk selanjutnya mendapatkan perhatian lebih dalam mendidik anaknya dirumah.

4. Manfaat penelitian perancangan sistem informasi berbasis web bagi siswa dapat mengetahui hasil pendataan emosi lebih cepat dan mudah.

\section{TINJAUAN PUSTAKA}

\subsection{Pengertian Sistem Informasi}

Sistem Informasi pada suatu sistem meliputi masukan data (input) yang kemudian diolah melalui suatu model dalam pemrosesan data, hasil informasi akan diatangkap kembali sebagai suatu input dan seterusnya, sehingga membentuk siklus informasi yang dapat diperoleh dari sistem informasi sebagai sistem khusus dalam organisasi untuk mengolah informasi tersebut.

Menurut Agus Mulyanto (Mulyanto, 2009:29), "Sistem informasi merupakan suatu komponen yang terdiri dari manusia, teknologi informasi, dan prosedur kerja yang memproses, menyimpan, menganalisis, dan menyebarkan informasi untuk mencapai suatu tujuan."

Sedangkan Menurut Sutabri (2012:46), Sistem informasi adalah suatu sistem didalam suatu organisasi yang mempertemukan kebutuhan pengolahan transaksi harian yang mendukung fungsi operasi organisasi yang bersifat manajerial dengan kegiatan strategi dari suatu organisasi untuk dapat menyediakan kepada pihak luar tertentu dengan laporanlaporan yang diperlukan.

\subsection{Perancangan Sistem Informasi}

Tahapan perancangan sistem dilakukan setelah tahapan analisis sistem dilakukan, maka analisis sistem telah mendapat gambaran dengan jelas apa yang harus dikerjakan. Dan bagi analisis untuk memikirkan bagaimana membentuk suatu sistem tersebut.

Menurut Siti Aisyah dan Nawang Kalbuana dalam jurnal CCIT (Aisyah dkk, 2011:203) Pada metode analisa sistem dan perancangan yang menggunakan metode yang dikenal dengan nama "System Develoment Life Cycle (SDLC). SDLC merupakan metodelogi umum dalam pengembangan sistem yang menandai kemajuan dai usaha analisa dan desain". Langkah-langkah SDLC meliputi fase-fase sebagai berikut:

1. Perancangan Sistem

Dalam tahapan perencanaan sistem ini dijelaskan bagaimana langkah-langkah 
dalam perancangan aplikasi kemahasiswaan dengan teknologi mobile.

2. Analisa Sistem

Melakukan analisa sistem yang akan dirancang, serta melakukan penelitian terhadap kebutuhan-kebutuhan sistem, apa saja kekurangannya.

3. Perancangan

Yaitu tahapan untuk melakukan perancangan aplikasi mobile, terdapat tiga tahapan perancangan, yaitu: perancangan interface, perancangan isi, dan perancangan program.

\subsection{Metodologi Penelitian Sistem Informasi}

\subsubsection{Metode Pengumpulan Data}

$$
\text { "Metode pengumpulan data }
$$
merupakan langkah yang paling strategis dalam penelitian, karena tujuan utama dari penelitian adalah mendapatkan data".

Metode Pengumpulan Data yang digunakan dalam penyusunan Tugas Akhir ini adalah sebagai berikut:

1. Metode Penelitian Langsung (Observation)

Teknik ini dilakukan dengan cara mengadakan pengamatan atau tinjauan secara langsung sehingga mengetahui dan memperoleh data sesuai dengan proses penyewaan di Rental Video Keyran.

2. Metode Wawancara (Interview)

Teknik ini dilakukan untuk mendapatkan informasi secara lengkap, yaitu dengan melakukan tanya jawab dengan pihak yang bersangkutan.

3. Metode Pustaka (Library)

Dalam hal ini penulis juga melakukan studi pustaka dengan cara mempelajari buku-buku yang ada diperpustakaan dan membaca dari berbagai sumber seperti internet yang berisi teori sebagai referensi yang berhubungan dengan tema atau penyusunan Laporan Tugas Akhir ini.

\subsubsection{Model Pengembangan Waterfall}

Menurut pressman (2010) tahapan dalam model process waterfall sebagai berikut:
1. Communication

Tahap ini merupakan analisa kebutuhan software dan tahap metode pengumpulan data.

2. Planning

Tahap planning merupakan lanjutan dari proses communication tahapan dilakukan analisa sistem berjalan, identifikasi masalah dan alternatif pemecahan masalah.

3. Modeling

Tahap ini pemodelan menggunakan UML sebagai alat bantu untuk menggambarkan perancangan sistem yang akan di buat.

4. Contruction

Tahapan ini terdiri dari:
a. Pemograman Bahasa pemograman
menggunakan Java.

b. Testing Pengujian sistem informasi

5. Deployment menggunakan Black Box

Tahapan ini biasa dikatakan final dalam pembuatan sebuah software atau system. Setelah melakukan pemodelan dan pengkodean maka sistem yang sudah jadi akan digunakan oleh user, kemudian software yang telah dibuat harus dilakukan pemeliharaan secara berkala.

\subsection{Definisi Kasus yang dirancang}

\subsubsection{Emosi}

\subsubsection{Definisi Emosi}

Pengertian Emosi menurut Soergada Poerbakawatja ialah respons terhadap suatu perangsang yang menyebabkan perubahan fisiologis disertai perasaan yang kuat dan biasanya mengandung kemungkinan untuk meletus. Respons demikian terjadi baik terhadap perasaanperasaan eksternal maupun internal. Dengan pengertian emosi menurut Soergada ini terlihat jelas perbedaan antara perasaan dengan emosi, bahkan terlihat jelas bahwa perasaan termasuk ke dalam emosi atau menjadi bagian dari emosi.

\subsubsection{Jenis-jenis Emosi}

Ekspresi emosi anak berbeda antara satu dengan yang lainnya. Anak bertipe kepribadian ekstrovert lebih mudah diketahui gejolak emosinya dibandingkan anak introvert. Hal tersebut menuntut orangtua untuk jeli 
mengamati perilaku anak. Salah satunya dengan kenali jenis emosi anak yang menurut Hurlock antara lain:

\section{Marah}

Marah adalah jenis emosi anak yang disebabkan oleh terhambatnya keinginan. Ekspresi emosi anak yaitu menangis, berteriak, memukul, membanting barang, dan berguling-guling di lantai.

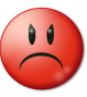

\section{Takut}

\section{Gambar 2.1 Emoticon Marah}

Takut adalah jenis emosi anak yang berkaitan erat dengan upaya pertahanan diri terhadap bahaya. Rasa takut juga bisa ditimbulkan oleh ingatan tentang pengalaman yang tidak menyenangkan. Ekspresi emosi anak yaitu panik, lari, menghindar, menutup muka, bersembunyi, dan menangis.

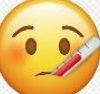

\section{Cemburu}

\section{Gambar 2.2 Emoticon Takut}

Cemburu adalah jenis emosi anak karena adanya rasa tidak nyaman dengan kehadiran seseorang yang dianggap sebagai kompetitor. Biasanya terjadi pada kelahiran adik di tengah keluarga. Anak merasa adanya pengalihan perhatian dari orangtua dan orangorang dewasa di sekitarnya. Ekspresi emosi anak yaitu usil, tidak menyukai bahkan melukai adiknya.

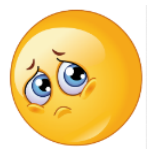

\section{Cemburu \\ Gambar \\ 2.3 \\ Emoticon}

\section{Gembira atau Senang}

Gembira adalah jenis emosi anak sebagai bentuk ungkapan perasaan terhadap situasi atau sesuatu yang sesuai dengan harapan. Ekspresi emosi anak bermacam-macam yaitu tepuk tangan, tertawa, tersenyum, melompat-lompat kegirangan, mencium benda atau orang yang disayanginya.

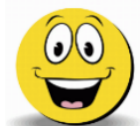

\section{Gambar 2.4 Emoticon Ceria/Gembira}

5. Sedih

Sedih adalah jenis emosi anak atas kehilangan sesuatu yang dianggap penting dan dicintainya. Bisa karena berpisah dengan teman bermain atau kehilangan binatang kesayangannya. Ekspresi emosi anak yaitu menangis, berwajah murung, ngambek atau tidak mau makan.

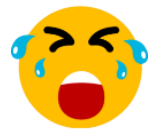

Gambar 2.5 Emoticon Sedih

2.4.2 Pegawai Tenaga Kependidikan (PTK)

2.4.2.1 Kepala Sekolah

Menurut PP RI Nomor 19

Tahun 2017 dalam pasal 54 menyatakan bahwa tugas utama kepala sekolah adalah melaksanakan tugas manajerial, pengembangan, kewirausahaan, dan supervise guru dan tenaga kependidikan.

\subsubsection{Guru Budi Pekerti}

Guru Budi Pekerti adalah seseorang yang ditugaskan sebagai guru untuk menangani dan melaksanakan dalam menangani setiap permasalahan siswa di sekolah.

\subsubsection{Guru Kelas}

Guru Kelas atau Wali Kelas adalah Guru yang membantu Kepala Sekolah untuk membimbing siswa dalam mewujudkan disiplin kelas, sebagai manajer dan motivator untuk membangkitkan gairah/minat siswa untuk beprestasi di kelas.

\subsubsection{Siswa}

Pengertian yang sama diambil dari (Kompas Gramedia, 2005) Siswa adalah komponen masukan dalam system pendidikan, yang selanjutnya diproses dalam proses pendidikan, sehingga menjadi manusia yang berkualitas sesuai dengan tujuan pendidikan nasional.

\subsection{Konsep Pemrograman Berbasis Web}

\subsubsection{Pemrograman Berbasis Web}


Menurut Hidayat (2010:2)[8] , "Website atau situs dapat diartikan sebagai kumpulan halaman-halaman yang digunakan untuk menampilkan informasi teks, gambar diam atau gerak, animasi, suara, dan atau gabungan dari semuanya, baik yang bersifat statis maupun dinamis yang membentuk satu rangkaian bangunan yang saling terkait, yang masingmasing dihubungkan dengan jaringanjaringan halaman.

Browser adalah perangkat lunak untuk mengakses halaman web seperti Internet Explorer, Mozilla Firefox, Opera, Safari, dan lain-lain.

Dapat disimpulkan Website adalah sebuah tempat di Internet, yang menyajikan informasi dengan berbagai macam format data seperti text, image, bahkan video dan dapat diakses menggunakan berbagai aplikasi klien sehingga memungkinkan penyajian informasi yang lebih menarik dan dinamis dengan pengelolaan yang terorganisasi.

\subsubsection{PHP}

Menurut Arief (2011c:43) PHP adalah Bahasa server-side -scripting yang menyatu dengan HTML untuk membuat halaman web yang dinamis. Karena PHP merupakan server-sidescripting maka sintaks dan perintahperintah PHP akan diesksekusi diserver kemudian hasilnya akan dikirimkan ke browser dengan format HTML.

\subsubsection{Xampp}

Pada umumnya Xampp merupakan perangkat lunak bebas dan mendukung berbagai macam sistem operasi. Xampp sendiri adalah kompilasi beberapa program yang digabungkan. Fungsi dari Xampp ini digunakan untuk server local host atau server yang berdiri sendiri dan terdiri dari beberapa program seperti perl, apache http server, penerjemah bahasa yang sudah ditulis sesuai dengan bahasa pemograman pop, dan mysql database. Sedangkan nama Xampp sendiri adalah singkatan dari $X$ yaitu empat sistem operasi apapun, apache, mysql, perl dan php.

\subsubsection{PHPMyAdmin}

Menurut Sibero (2011e:376) "PhpMyAdmin adalah aplikasi web yang dibuat oleh phpMyAdmin.net. phpMyAdmin digunakan untuk administrasi database MySQL". Program ini digunakan untuk mengakses database MySQL. Perintah untuk membuat tabel dapat menggunakan form yang sudah tersedia pada PhpMyAdmin atau dapat langsung menuliskan script pada menu SQL. PhpMyAdmin dijalankan dengan cara mengetik http://localhost/phpmyadmin pada web browser.

\subsection{Pengertian Codelgniter}

Codelgniter adalah sebuah web application network yang bersifat open source yang digunakan untuk membangun aplikasi php dinamis.

Codelgniter menjadi sebuah framework PHP dengan model MVC (Model, View, Controller) untuk membangun website dinamis dengan menggunakan PHP yang dapat mempercepat pengembang untuk membuat sebuah aplikasi web. Selain ringan dan cepat, Codelgniter juga memiliki dokumentasi yang super lengkap disertai dengan contoh implementasi kodenya. Dokumentasi yang lengkap inilah yang menjadi salah satu alasan kuat mengapa banyak orang memilih Codelgniter sebagai framework pilihannya.

\subsubsection{MySql}

Menurut Arief (2011e:151)
MySQ (My Structure Query
Languange) adalah "salah satu jenis
database server yang sangat terkenal
dan banyak digunakan untuk
membangun aplikasi web yang
menggunakan database sebagai
sumber dan pengelolaan datanya".
Mysql bersifat open source dan
menggunakan SQL (Structured Query
Languange). MySQL biasa dijalankan
diberbagai platform misalnya windows
Linux, dan lain sebagainya.

\subsection{UML}

UML Adalah sebuah bahasa untuk menetukan, visualisasi, kontruksi, dan mendokumentasikan artifact (bagian dari informasi yang digunakan atau dihasilkan dalam suatu proses pembuatan perangkat 
lunak. Artifact dapat berupa model, deskripsi atau perangkat lunak) dari system perangkat lunak, seperti pada pemodelan bisnis dan system non perangkat lunak lainnya.

UML merupakan suatu kumpulan teknik terbaik yang telah terbukti sukses dalam memodelkan sistem yang besar dan kompleks. UML tidak hanya digunakan dalam proses pemodelan perangkat lunak, namun hampir dalam semua bidang yang membutuhkan pemodelan.

\subsubsection{Diagram UML}

Diagram berbentuk grafik yang menunjukkan simbol elemen model yang disusun untuk mengilustrasikan bagian atau aspek tertentu dari sistem. Sebuah diagram merupakan bagian dari suatu view tertentu dan ketika digambarkan biasanya dialokasikan untuk view tertentu. Adapun jenis diagram antara lain :

\subsubsection{Use Case Diagram}

Use case adalah abstraksi dari interaksi antara system dan actor. Use case bekerja dengan cara mendeskripsikan tipe interaksi antara user sebuah sistem dengan sistemnya sendiri melalui sebuah cerita bagaimana sebuah sistem dipakai. Use case merupakan konstruksi untuk mendeskripsikan bagaimana sistem akan terlihat di mata user. Sedangkan use case diagram memfasilitasi komunikasi diantara analis dan pengguna serta antara analis dan client.

\subsubsection{Sequence Diagram}

Sequence diagram digunakan untuk menggambarkan perilaku pada sebuah scenario. Kegunaannya untuk menunjukkan rangkaian pesan yang dikirim antara objectjuga interaksi antara object, sesuatu yang terjadi pada titik tertentu dalam eksekusi sistem.

\subsubsection{Activity Diagram}

Menggambarkan rangkaian aliran dari aktivitas, digunakan untuk mendeskripsikan aktifitas yang dibentuk dalam suatu operasi sehingga dapat juga digunakan untuk aktifitas lainnya seperti use case atau interaksi.

\subsubsection{Class Diagram}

Class adalah dekripsi
kelompok obyek-obyek dengan
property, perilaku (operasi) dan relasi yang sama. Sehingga dengan adanya class diagram dapat memberikan pandangan global atas sebuah sistem. Hal tersebut tercermin dari class- class yang ada dan relasinya satu dengan yang lainnya. Sebuah sistem biasanya mempunyai beberapa class diagram. class diagram sangat membantu dalam visualisasi struktur kelas dari suatu sistem.

\subsection{Konsep Dasar Black Box Testing}

Menurut pandangan beberapa ahli Black Box Testing dapat diartikan, antara lain sebagai berikut:

Menurut Soetam Rizky (2011:264), berpendapat bahwa "Black box testing adalah tipe testingyang memperlakukan perangkat lunak yang tidak diketahui kinerja internalnya.Sehingga para tester memandang perangkat lunak seperti layaknya sebuah "kotakhitam" yang tidak penting dilihat isinya, tapi cukup dikenai proses testing di bagian luar".

Menurut Agustiar Budiman (2012:4)[27], berpendapat bahwa "Pengujian black box merupakan metode perancangan data uji yang didasarkan pada spesifikasi perangkat lunak. Data uji dibangkitkan, dieksekusi pada perangkat lunak dan kemudian keluaran dari perangkat lunak diuji apakah telah sesuai dengan yang diharapkan."

\section{METODOLOGI PENELITIAN}

3.1 Tempat dan Waktu Penelitian Penelitian yang penulis lakukan bertempat di SDIT BUNAYYA PERMATA TANGERANG dari bulan Agustus 2018 sampai bulan Oktober 2018.

\subsection{Metode Pengumpulan Data}

Metode - metode yang di gunakan untuk mendapatkan informasi dan data - data yang diperlukan adalah sebagai berikut:

\subsubsection{Metode Interview / wawancara}

Metode wawancara yaitu pengumpulan data dengan jalan tanya jawab lisan kepada para pegawai di SDIT Bunayya secara sepihak yang dikerjakan secara sistematis dan berlandaskan pada tujuan penelitian. 


\subsubsection{Metode Observasi}

Observasi adalah pengamatan dan pencatatan secara sistimatik terhadap unsur-unsur yang tampak dalam suatu gejala atau gejala-gejala dalam objek penelitian pada keadaan sistem informasi emosi siswa di SDIT Bunayya.

\subsubsection{Metode Kepustakaan}

Yaitu dengan mengumpulkan berbagai sumber - sumber referensi baik berupa buku absensi dan buku agenda pada SDIT Bunayya.

\subsection{Metode Analisis Sistem}

Pada tahap analisis sistem, penulis menggunakan pendekatan Object Oriented Analysis (OOA) atau analisis berorientasi obyek dengan UML. Proses analisis dilakukan terhadap hasil tahapan pengumpulan data dengan wawancara, obsevasi, dan studi pustaka untuk mendapatkan spesifikasi kebutuhan sistem yang akan dikembangkan.

\subsection{Metode Pengembangan Perangkat Lunak \\ Untuk metode pengembangan perangkat} lunak yang digunakan adalah metode/model pengembangan sistem waterfall karena dalam penelitian penulis mengerjakannya secara bertahap.

Model pengembangan sistem waterfall dapat digambarkan sebagai berikut:

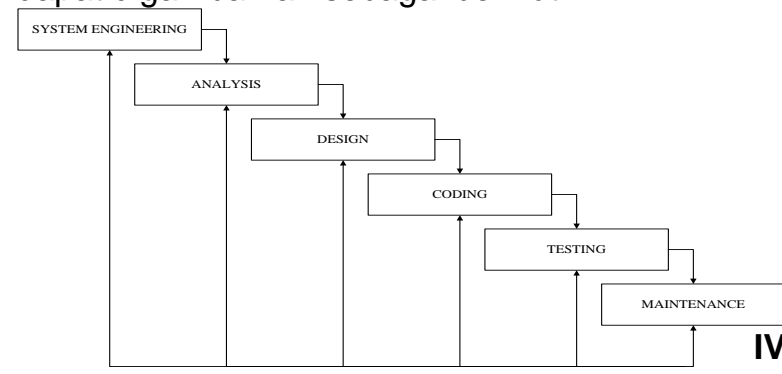

\section{Gambar $3.1 \quad$ Model Waterfall Pressman}

\subsection{Metode Pengembangan Sistem}

Metode dalam pengembangan sistem ini menggunakan System Development Life Cycle (SDLC) dengan model process waterfall. Menurut pressman (2010) tahapan dalam model process waterfall sebagai berikut:

1. Communication

Tahap ini merupakan analisa kebutuhan software dan tahap metode pengumpulan data.
2. Planning

Tahap planning merupakan lanjutan dari proses communication tahapan dilakukan analisa sistem berjalan, identifikasi masalah dan alternatif pemecahan masalah.

3. Modeling

Tahap ini pemodelan menggunakan UML sebagai alat bantu untuk menggambarkan perancangan sistem yang akan di buat.

4. Contruction

Tahapan ini terdiri dari:

a. Pemograman

Bahasa pemograman menggunakan Java.

b. Testing Pengujian sistem informasi menggunakan Black Box

5. Deployment

Tahapan ini biasa dikatakan final dalam pembuatan sebuah software atau system. Setelah melakukan pemodelan dan pengkodean maka sistem yang sudah jadi akan digunakan oleh user, kemudian software yang telah dibuat harus dilakukan pemeliharaan secara berkala.

\subsection{Metode Pengujian Black Box}

Equivalence Partioning merupakan metode uji coba Black Box yang membagi domain input dari program menjadi beberapa kelas data dari kasus uji coba yang dihasilkan. Kasus uji penanganan single yang ideal menemukan sejumlah kesalahan (misalnya: kesalahan pemrosesan dari seluruh data karakter) yang merupakan syarat lain dari suatu kasus yang dieksekusi sebelum kesalahan umum diamati.

\section{HASIL DAN PEMBAHASAN}

4.1 Analisa Sistem Berjalan

\subsubsection{Gambaran Sistem Berjalan}

Berdasarkan analisa dari sistem yang diamati yaitu bahwa sistem pencatatan emosi yang berjalan terdapat beberapa kekurangan dari segi efektifitas dan efisiensi sistem yang sekarang digunakan, membutuhkan proses yang cukup panjang serta melibatkan banyak pihak dalam pembuatan daftar emosi , serta kekhawatiran data yang mungkin tidak valid karena berbagai macam hal, seperti daftar kehadiran yang rusak, dan hilang.

\subsubsection{Prosedur Sistem Berjalan}


Analisa difokuskan pada sitem pendataan emosi siswa yang terdapat di SDIT Bunayya. Berdasarkan metode analisis yang digunakan, maka berikut merupakan gambaran sistem yang sedang berjalan pada sistem informasi emosi siswa pada SDIT Bunayya :

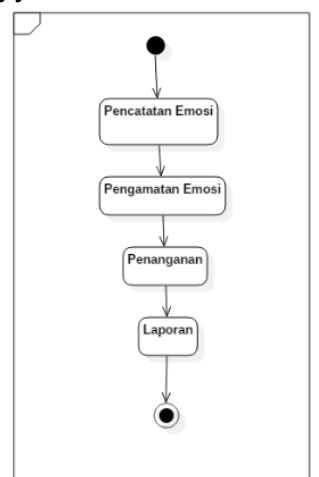

\section{Gambar 4.1 Flowchart Sistem yang berjalan}

1. Pencatatan Emosi

Guru mencatat emosi siswa atau hanya mengingatnya saja.

2. Pengamatan Emosi

Guru Kelas, Guru Budi Pekerti melakukan pengamatan terhadap siswa yang memiliki masalah dengan emosinya.

3. Penangan Siswa

Guru Kelas dan Guru Budi Pekerti melakukan penangan terhadap siswa dengan pemanggilan.

4. Laporan

Laporan Guru Kelas dan Budi Pekerti hanya dijelaskan secara lisan kepada kepala sekolah.

\subsection{Planning}

\subsubsection{Kebutuhan Sistem yang di Usulkan}

a. Kebutuhan Software

1. Xampp 3.2.1

2. MySQL 5.6.21

3. Google Chrome

b. Kebutuhan Hardware

1. Intel Core i3

2. RAM 4 GB DDR4

3. Hard Disk 1 TB

4. VGA Nvidia 720gtx

5. Monitor LED 14'

6. Keyboard dan Mouse

\subsubsection{Hasil Pengumpulan Data}

Adapun penyimpanan data emosisiswa adalah sebagai berikut :

1. Buku Kehadiran Siswa

2. Buku Agenda Siswa

\subsubsection{Evaluasi Sistem yang sedang berjalan \\ Setelah penulis melakukan analisa pada sistem yang berjalan pada sistem}

emosi di SDIT Bunayya yang masih tidak menggunakan pencatatan emosi dapat disimpulkan kekurangan-kekurangan dalam sistem yang berjalan diantaranya sebagai berikut :

Tabel 4.1 Evaluasi Sistem yang sedang Berjalan

\begin{tabular}{|c|c|c|c|}
\hline No. & Masalah & Worker & $\begin{array}{l}\text { Pemecahan } \\
\text { Masalah }\end{array}$ \\
\hline 1 & $\begin{array}{l}\text { Pencatatan } \\
\text { Emosi } \\
\text { Siswa }\end{array}$ & Guru Kelas & $\begin{array}{l}\text { Dibuatnya sistem } \\
\text { informasi yang } \\
\text { dapat memproses } \\
\text { pencatatan emosi. }\end{array}$ \\
\hline 2 & $\begin{array}{l}\text { Merekap } \\
\text { Data Emosi } \\
\text { Siswa }\end{array}$ & Guru Kelas & $\begin{array}{lr}\text { Dibuatnya } & \text { sistem } \\
\text { informasi } & \text { yang } \\
\text { memiliki database } \\
\text { yang dapat } \\
\text { mengelola data- } \\
\text { data secara efisien. }\end{array}$ \\
\hline 4 & $\begin{array}{l}\text { Menginput } \\
\text { Data Guru } \\
\text { dan Siswa }\end{array}$ & $\begin{array}{l}\text { Staff } \\
\text { Administrasi }\end{array}$ & $\begin{array}{lr}\text { Dengan } & \text { Sistem } \\
\text { Informasi emosi } \\
\text { siswa berbasis web } \\
\text { Staff admin } & \text { tidak } \\
\text { perlu } & \text { lagi } \\
\text { menginput ulang } \\
\text { data guru dan } \\
\text { siswa }\end{array}$ \\
\hline 5 & $\begin{array}{l}\text { Membuat } \\
\text { Laporan }\end{array}$ & $\begin{array}{l}\text { Staff } \\
\text { Administrasi }\end{array}$ & $\begin{array}{lr}\text { Dengan } & \text { Sistem } \\
\text { Informasi } & \text { Emosi } \\
\text { siswa berbasis web } \\
\text { Staff Administrasi } \\
\text { dapat mencetak } \\
\text { laporan dengan } \\
\text { cepat tanpa perlu } \\
\text { ada edit ataupun } \\
\text { tambah data-data } \\
\text { lainnya }\end{array}$ \\
\hline
\end{tabular}

Berikut permasalahan yang ditemui dalam proses sistem yang berjalan antara lain :

1. Tidak ada pencatatan emosi yang dilakukan oleh Guru Kelas ataupun guru lain. ketika ada permasalahan hanya dari mengingat memori yang ada di fikiran guru-guru saja.

2. Tidak ada proses yang jelas tentang pengamatan yang dilakukan oleh Guru Kelas dan Guru Budi Pekerti.

3. Penanganan yang dilakukan Guru Budi Pekerti dan Guru Kelas hanya dilaporkan secara lisan tanpa adanya catatan yang diberikan sebagai bahan pertimbangan untuk tindakan lain yang siswa lakukan.

\subsubsection{Perancangan Sistem}

Perancangan sistem atau desain sistem yang dimaksud adalah tahap selanjutnya, dimana sebelumnya penulis sudah menganalisis proses yang sedang berjalan. Berdasarkan hasil dari analisis 
tersebut maka penulis mengusulkan sistem baru, yang mana kinerja dari suatu sistem yang baru diharapkan mengatasi kendalakendala atau permasalahan yang ada pada sistem yang sekarang berjalan.

\subsubsection{Tujuan Perancangan Sistem}

Tujuan dari perancangan sistem adalah sebagai gambaran umum pengembangan sistem usulan yang dapat memberikan spesifikasi sistem usulan perangkat lunak kepada pengguna dengan menganalisis kelemahan-kelemahan dalam sistem yang sudah ada dan mengembangkan sistem yang telah ada demi kenyamanan, kemudahan dan efisiesni.

Adapun tujuan perancangan aplikasi pengolahan data proyek adalah sebagai berikut:

1. Memberikan kemudahan kepada guru, kepala sekolah dan staff administrasi dalam mengolah laporan emosi siswa.

2. Dapat mempercepat proses pencatatan/penginputan data.

3. Mengurangi pencatatan data yang berulang-ulang.

\subsubsection{Gambaran Sistem yang diusulkan}

Perancangan sistem dilakukan untuk memberikan gambaran umum tentang sistem yang dikembangkan atau dirubah menjadi sistem yang baru. Tahapan desain sistem menjadi 2 maksud dan tujuan yaitu :

1. Untuk memenuhi kebutuhan kerja sistem informasi kepada pemakai sistem.

2. Untuk memberikan gambaran yang jelas dan rancang bangun yang lengkap kepada programmer.

Proses yang dapat dikerjakan oleh pengembangan sistem informasi emosi siswa meliputi :

1. Form Data Guru, pada menu ini Staff Administrasi bisa mengentry, mengubah dan menghapus data guru.

2. Form Data Siswa, pada menu ini Guru Kelas bisa mengentry, mengubah dan menghapus data siswa.

3. Form Input Data Emosi, pada menu ini guru kelas dapat mengentry, mengubah dan menghapus data emosi ssiwa.

4. Form Hasil Pengamatan Emosi, pada menu ini guru kelas dapat mengentry, mengubah dan menghapus data hasil pengamatan emosi siswa.
5. Cetak Laporan Emosi Siswa, pada menu ini staff administrasi dapat

4.3 Modelling mencetak laporan Emosi Siswa.

\subsubsection{Perancangan Sistem Usulan \\ 4.3.1.1 Usecase Diagram}

Use case adalah abstraksi dari interaksi antara system dan actor. Use case bekerja dengan cara mendeskripsikan tipe interaksi antara user sebuah sistem dengan sistemnya sendiri melalui sebuah cerita bagaimana sebuah sistem dipakai.

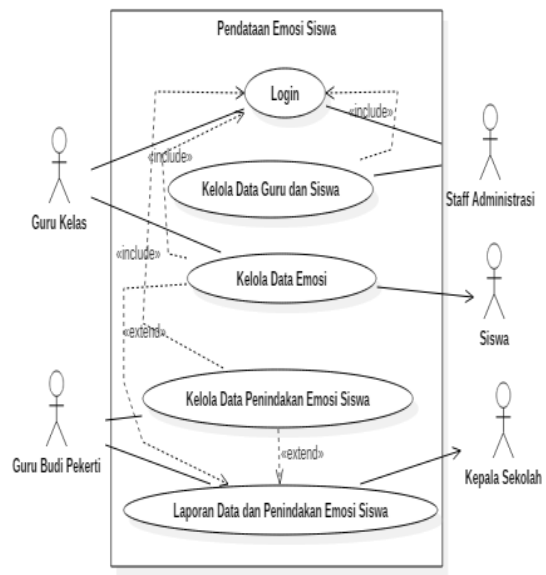

Gambar 4.2 Use Case Diagram

Sistem pada use case yang dirancang pada aplikasi ini memiliki enam aktor:

Tabel 4.2 Penjelasan Aktor

\begin{tabular}{|c|c|c|}
\hline No & Aktor & Penjelasan \\
\hline 1 & $\begin{array}{l}\text { Staff } \\
\text { Administra } \\
\text { si }\end{array}$ & $\begin{array}{l}\text { Admin bertugas menginput, edit } \\
\text { serta hapus data guru dan siswa. }\end{array}$ \\
\hline 2 & $\begin{array}{l}\text { Guru } \\
\text { Kelas }\end{array}$ & $\begin{array}{l}\text { Guru kelas bertugas untuk } \\
\text { menginput, edit serta hapus data } \\
\text { emosi. }\end{array}$ \\
\hline 3 & $\begin{array}{l}\text { Kepala } \\
\text { Sekolah }\end{array}$ & $\begin{array}{l}\text { Kepala Sekolah mendapatkan } \\
\text { laporan hasil tindakan guru budi } \\
\text { pekerti. }\end{array}$ \\
\hline 4 & Siswa & $\begin{array}{l}\text { Siswa adalah orang yang diamati } \\
\text { emosinya. }\end{array}$ \\
\hline 5 & $\begin{array}{l}\text { Guru Budi } \\
\text { Pekerti }\end{array}$ & $\begin{array}{l}\text { Guru Budi Pekerti adalah orang } \\
\text { yang menerima laporan catatan } \\
\text { emosi siswa dan melakukan } \\
\text { penindakan hasil dari pengamatan } \\
\text { emosi siswa. }\end{array}$ \\
\hline
\end{tabular}

\subsubsection{Statechart Diagram}

1. Statechart Login 


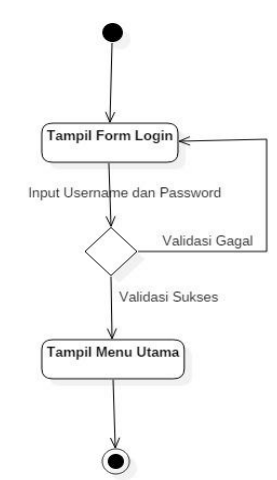

Gambar 4.3 Statechart Login Admin, Guru dan Kepala Sekolah

2. Statechart Kelola Data Guru dan Siswa

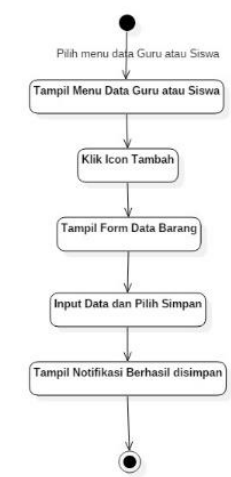

Gambar 4.4 Statechart Tambah Data Guru dan Siswa

3. Statechart Kelola Data Emosi Siswa

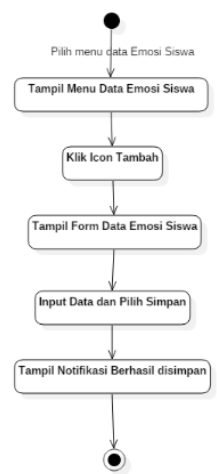

Gambar 4.5 Statechart Input Data Emosi Siswa

4. Statechart Laporan Data Emosi Siswa

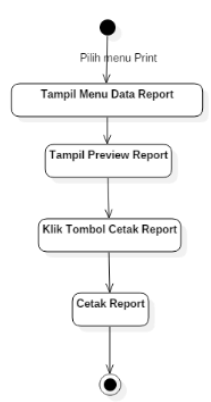

Gambar 4.6 Statechart Laporan Data Emosi Siswa

5. Statechart Kelola Data Penindakan Emosi Siswa

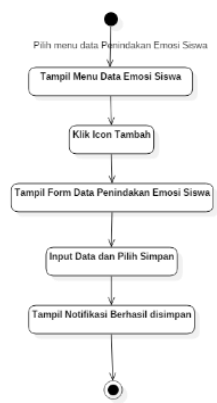

Gambar 4.7 Statechart Data Penindakan Emosi Siswa

6. Staetchart Laporan Data Penindakan Emosi Siswa

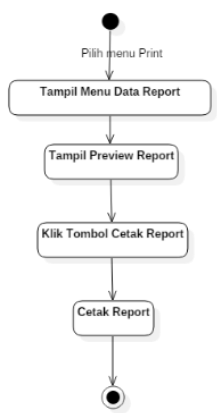

\section{Gambar 4.8 Statechart Laporan} Penindakan Emosi Siswa

4.3.3 Activity Diagram

1. Activity Login

a. Activity Login Admin

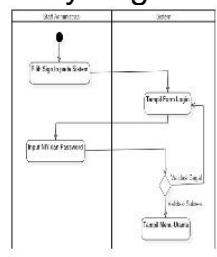

Gambar 4.9 Activity Login Admin

b. Activity Login Guru Kelas 


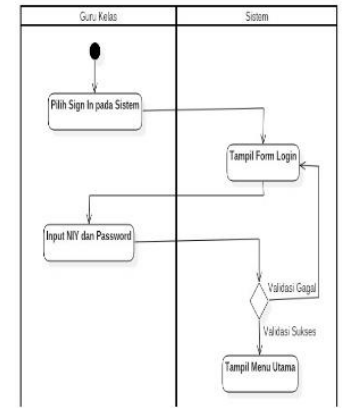

Gambar 4.10 Activity Login Guru Kelas c. Activity Login Guru Budi Pekerti

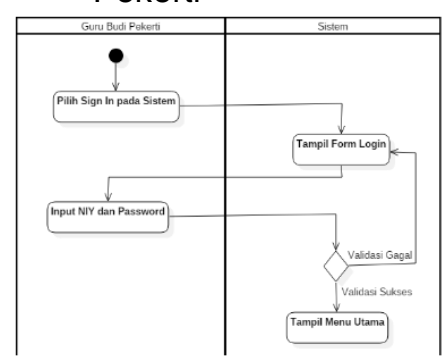

Gambar 4.11 Activity Login Budi Pekerti

2. Activity Kelola Data Guru dan Siswa

a. Tambah Data Siswa

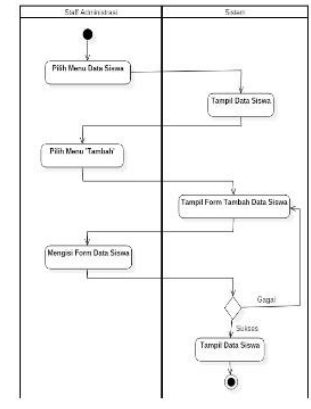

Gambar 4.12 Activity Tambah Data Siswa

b. Tambah Data Guru

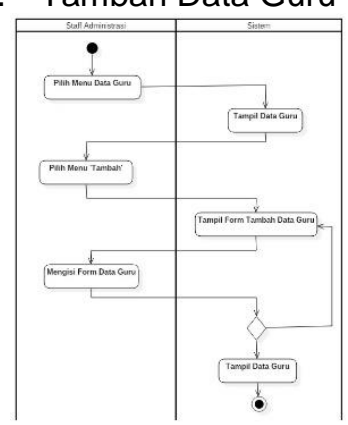

Gambar 4.13 Activity Tambah Data Guru

3. Activity Kelola Data Emosi Siswa

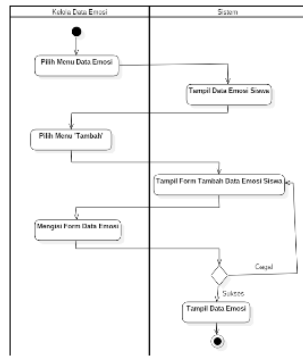

Gambar 4.14 Activity Input Data Emosi Siswa

4. Activity Laporan Data Emosi Siswa

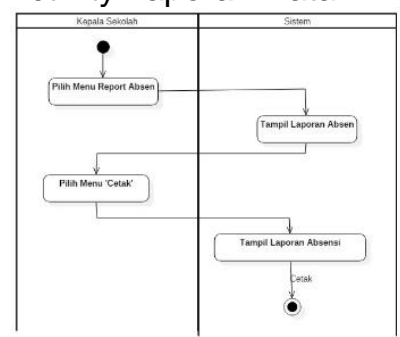

Gambar 4.15 Activity Laporan Data Emosi Siswa

5. Activity Input Data Penindakan Emosi Siswa

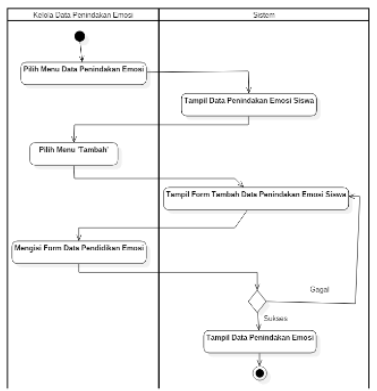

Gambar 4.16 Activity Input Data Penindakan Emosi Siswa

6. Activity Laporan Data Penindakan Emosi Siswa

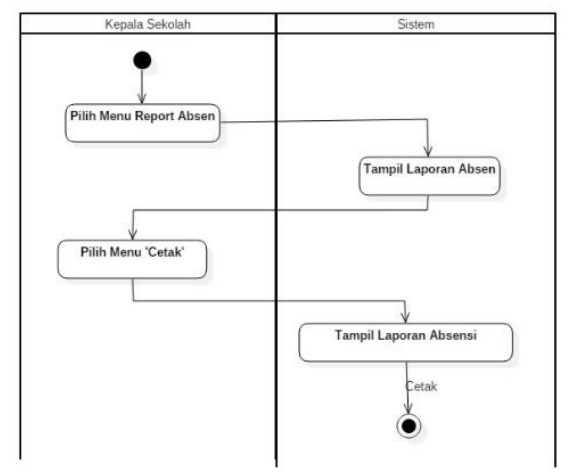

Gambar 4.17 Activity Laporan

\subsubsection{Sequence Diagram}

1. Sequence Login 


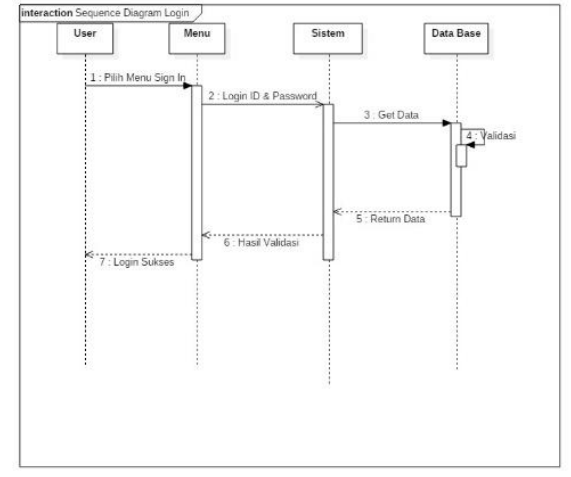

Gambar 4.18 Sequence Login

2. Sequence Kelola Data Guru, Siswa dan Emosi

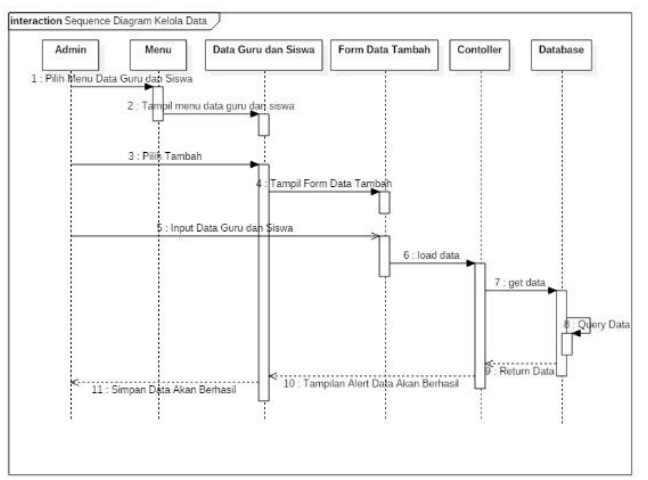

Gambar 4.19 Sequence Tambah Data Guru, Siswa , Data Emosi dan Data Penindakan Emosi Siswa

3. Sequence Laporan

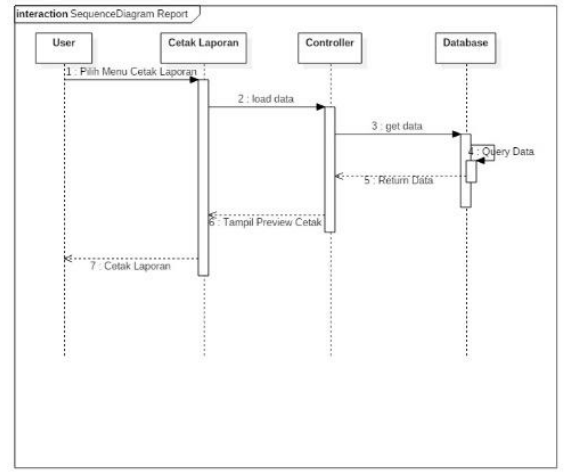

Gambar 4.20 Sequence Laporan Emosi Siswa dan Penindakan Emosi Siswa

\subsection{Rancangan Database}

Perancangan basis data dalam sistem informasi emosi siswa guru dan siswa menggunakan emoticon ini bertujuan agar dalam pengoperasian dan penerapannya dapat diperoleh data serta informasi yang lebih lengkap dan mempermudah dalam mengolah data.

\subsubsection{Class Diagram}

Diagram kelas (Classs Diagram) adalah diagram yang digunakan untuk menampilkan beberapa kelas yang ada dalam sistem/perangkat lunak yang sedang dikembangkan. Diagram kelas memberikan gambaran tentang sistem/perangkat lunak dan relasi-relasi yang ada. Adapun diagram kelas yang diusulkan pada sistem informasi emosi siswa guru dan siswa menggunakan emoticon adalah sebagai berikut :
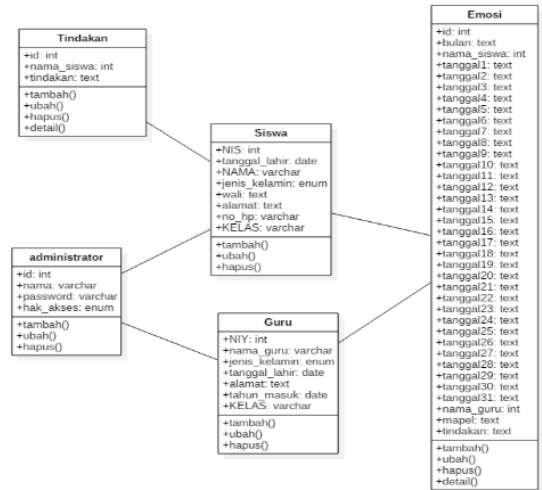

\section{Gambar 4.21 Class Diagram}

Class diagram Sistem Informasi Emosi Siswa menggunakan emoticon memiliki beberapa kelas, yaitu emosi, administrator, Guru, Siswa, tanggapan. Dimana administrator ber-relasi dengan siswa dan guru.

\subsection{Implementasi Sistem}

\subsubsection{Form Login}

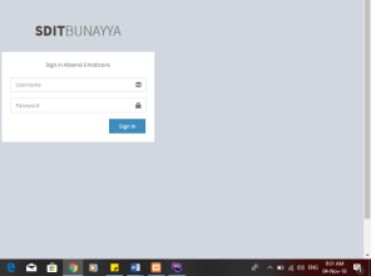

Gambar 4.30 Tampilan Login

\subsubsection{MenuUtama}

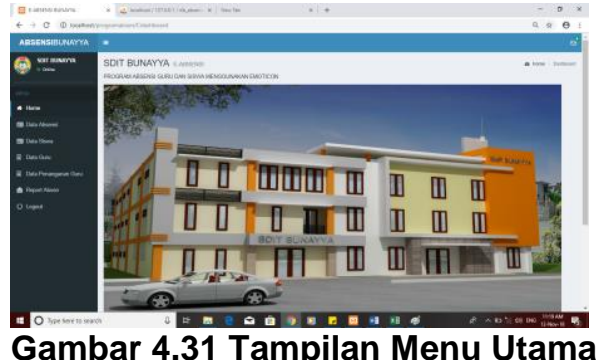

\subsubsection{Menu Data Emosi}




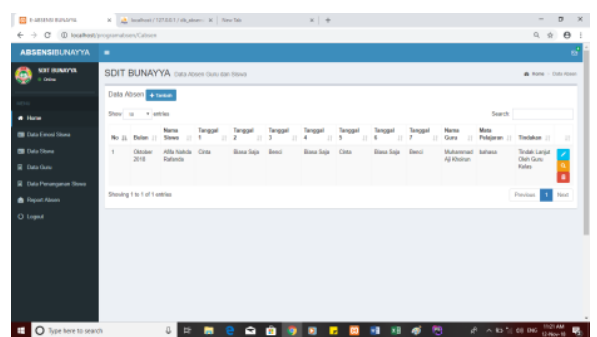

Gambar 4.32 Tampilan Menu Data Emosi

4.5.4 Menu Input Data Emosi

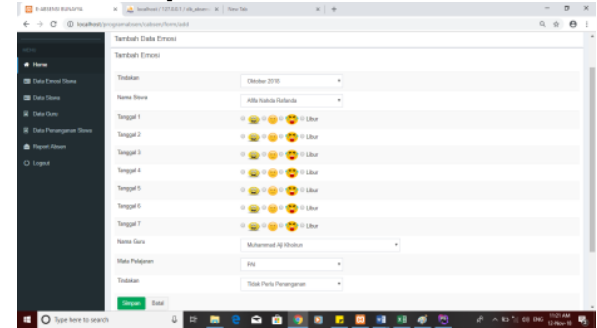

Gambar 4.33 Tampilan Menu Input Data Emosi

\subsubsection{Menu Data Penanganan Siswa}

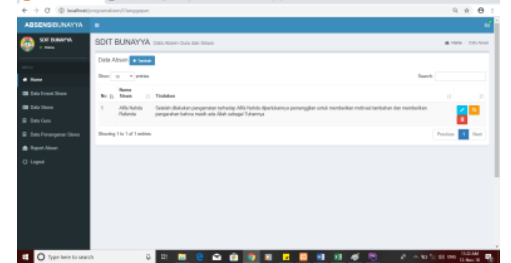

Gambar 4.34 Tampilan Menu Data

$$
\text { Penanganan Siswa }
$$

4.5.6 Input Data Penanganan Siswa

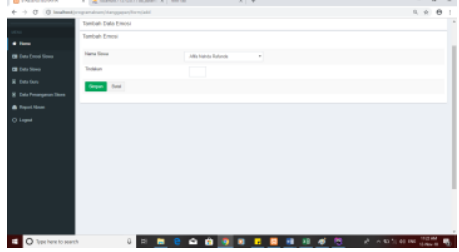

Gambar 4.35 Tampilan Menu Input Data Penanganan Emosi

\subsubsection{Menu Data Siswa}

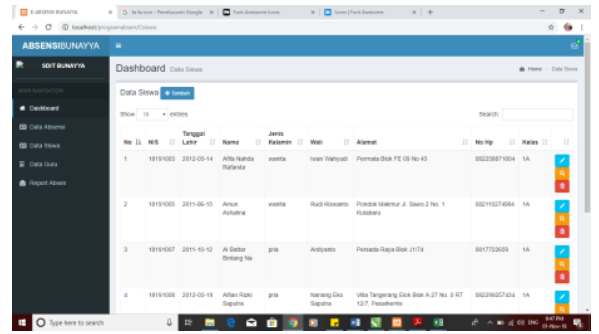

Gambar 4.36 Tampilan Menu Data Siswa

\subsubsection{Menu Input Data Siswa}

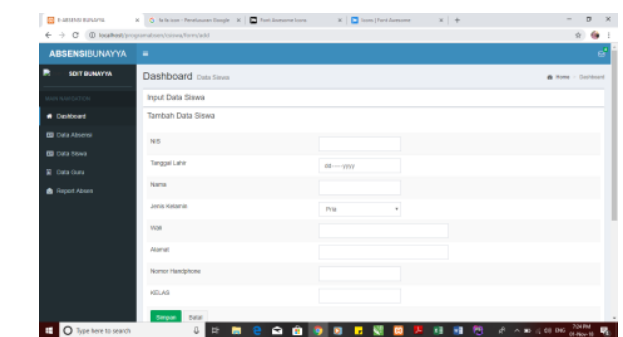

Gambar 4.37 Tampilan Menu Input Data Siswa

\subsubsection{Menu Data Guru}

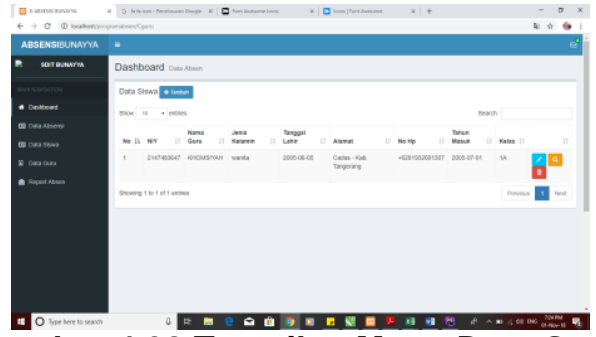

Gambar 4.38 Tampilan Menu Data Guru

\subsubsection{Menu Input Data Guru}

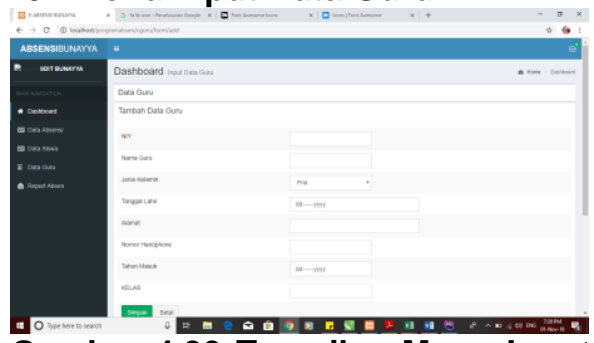

Gambar 4.39 Tampilan Menu Input Data Guru

\subsubsection{Menu Report}

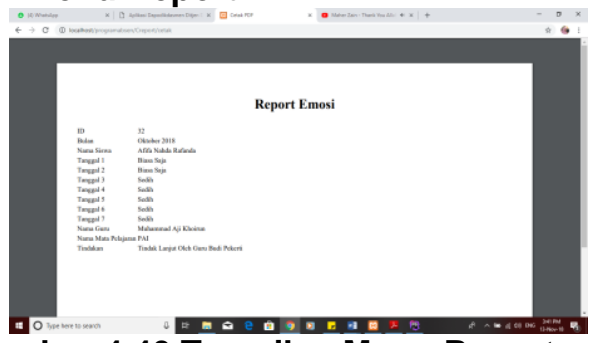

Gambar 4.40 Tampilan Menu Report

\subsection{Deployment}

Pada tahap ini adalah menyerahkan kepada pengguna dan melakukan perawatan terhadap s istem yang sudah dirancang, serta berharap adanya umpan balik dari pengguna dan instansi untuk meperbaiki dan menambahkan proses kerja.

\section{KESIMPULAN DAN SARAN}

5.1 Kesimpulan

Pengembangan Sistem Informasi

Pendataan Emosi siswa menggunakan 
emoticon diharapkan dapat mengurangi permasalahan - permasalahan yang berkaitan dengan proses emosi siswa di SDIT Bunayya.

Dari penelitian dan penulisan yang telah penulis uraikan, maka dapat ditarik kesimpulan sebagai berikut:

1. Proses Pendataan emosi yang terjadi di SDIT Bunayya saat di awal penelitian tidak ada pencatatan, hanya guru melaporkan secara lisan kepada Guru Budi Pekerti atau kepala sekolah untuk ditindaklanjuti dalam penangan siswa yang bermasalah dengan emosinya.

2. Kendala yang terjadi pada saat penangan emosi siswa karena tidak adanya data yang valid, Guru Budi Pekerti hanya bisa menerka-nerka dan hanya bisa memberikan saran tanpa melihat data yang valid.

3. Berdasarkan hasil peneletian yang dilakukan oleh penulis berdasarkan data-data yang diperoleh maka dirancanglah sebuah sistem informasi berbasis web mengguanakan metode waterfall dan memanfaatkan framework Codelginter yang dapat menyimpan, mengolah data, menganalisis dan memberikan laporan emosi siswa sebagai bahan pertimbangan dalam penanganan emosi siswa.

4. Laporan pendataan emosi dan penangan emosi siswa diberikan kepada guru budi pekerti dan kepala sekolah dengan di validasi atau di tandatangani oleh guru kelas dan guru budi pekerti. Laporan data emosi berisikan emosi yang terjadi pada siswa setiap harinya pada saat proses pembelajaran dan laporan penangan siswa berisikan hal-hal yang sudah dilakukan oleh guru kelas dan guru budi pekerti dalam menangani siswa yang memiliki masalah dengan emosinya.

\subsection{Saran}

Penulis menyadari masih ada kekurangan dalam sistem informasi ini. Adapun saran-saran penulis untuk pengembangan selanjutnya dan penerapan sistem informasi yang akan diusulkan antara lain:

1. Perlu adanya grafik statistik secara statistik untuk menampilkan hasil emosi siswa setiap bulannya.
2. Perlu adanya tim khusus dalam penangan siswa sehingga dalam mengolah data informasi menjadi lebih cepat dan lebih akurat.

\section{REFERENSI}

[1]. Agus Mulyanto. 2009. Sistem Informasi Konsep dan Aplikasi. Pustaka Pelajar. Yogyakarta.

[2]. Aisyah, Siti, dkk. 2011. Perkembangan dan Konsep Dasar Pengembangan Anak Usia Dini. Jakarta : Universitas Terbuka

[3]. Alexander F. K. Sibero, 2011, Kitab Suci Web Programing, MediaKom,. Yogyakarta.

[4]. Arief M Rudianto. 2011. Pemrograman Web Dinamis menggunakan PHP dan MySQL. Yogyakarta : Andi Offset

[5]. Arifianto, Teguh. 2011. Membuat Interface Aplikasi Android Lebih Keren dengan LWIT. Yogyakarta : Andi.

[6]. Budiman, Agustiar. 2012. Pengujian Perangkat Lunak dengan Metode Black Box

[7]. Pada Proses Pra Registrasi UserVia Website. Makalah, halaman: 4.

[8]. Connolly, Thomas and Begg, Carolyn. (2010). Database Systems A Practical

[9]. Approach to Design, Implementation, and Management Fifth Edition. Boston:

Pearson Education.

[10]. Panerbit PT Elex Media Komputindo.

[11]. Hartono, Bambang. 2013. Sistem Informasi Manajemen Berbasis Komputer. Jakarta : PT Rineka Cipta.

[12]. Hidayat, Rahmat. 2010. Cara Praktis Membangun Website Gratis. Jakarta: PT. Elex Media Komputindo.

[13]. Indrajani. 2015. Database Design (Case Study All in One). Jakarta: PT Elex Media. Komputindo.

[14]. Kurniawan, B. 2008. Desain Web Praktis dengan CSS. Jakarta: Elex Media

[15]. Komputindo.

[16]. Rizky Soetam, "Konsep Dasar Rekayasa Perangkat Lunak", Jakarta: Prestasi. Pustaka, 2011.

[17]. Stephanus Hermawan Susanto. 2011. Mudah Membuat Aplikasi Android. Yogyakarta : Andi.

[18]. Sugiyono. 2013. Metode Penelitian Pendidikan Pendekatan Kuantitatif, kualitatif, dan R\&D. Bandung: Alfabeta

[19]. Tata Sutabri. 2012. Analisis Sistem Informasi. Andi. Yogyakarta.

[20]. Yuni Sugiarti "Analisis \& Perancangan UML (Unified Modeling Language)" 2013 Penerbit Graha IImu. 